NBER WORKING PAPER SERIES

\title{
NEOCLASSICAL AND SOCIOLOGICAL PERSPECTIVES ON SEGMENTED LABOR MARKETS
}

\author{
Kevin Lang
}

William T. Dickens

Working Paper No. 2127

NATIONAL BUREAU OF ECONOMIC RESEARCH 1050 Massachusetts Avenue

Cambridge, MA 02138

January 1987

The research reported here is part of the NBER's research program in Labor Studies. Any opinions expressed are those of the authors and not those of the National Bureau of Economic Research. 
NBER Working Paper \#2127 January 1987

Neoclassical and Sociological Perspectives on Segmented Labor Markets

\begin{abstract}
Neoclassical theory has been misrepresented in the segmented economy literature. Consequently, most tests of "structural" vs. "neoclassical" models are inadequate. Moreover, segmented economy theorists have concentrated on the least significant departures of segmented models from neoclassical economics. In fact, neoclassical economists have developed elements of a segmented labor market model which is similar to the segmented economy theories. We sketch this model and argue that the neoclassical model gives a precise meaning to the concept of dual or segmented labor markets but does not suggest that a classification system for job characteristics must rely on a single dimension.
\end{abstract}

Kevin Lang

School of Social Sciencs University of California

Irvine, CA 92717
William T. Dickens Department of Economics University of California Berkeley, CA 94720 
TABLE OF CONTENTS

I. Introduction

II. Neoclassical Wage Determination

III. The Challenge of Segmented Labor Market Theories to Orthodox Theory

IV. The Sociological Response

V. Testing for Queues

VI. Notes for a Neoclassical Model of Labor Market Stratification

VII. Some Concluding Remarks 


\section{Introduction}

Segmented labor market models gained popularity in economics during the late 1960s and early 1970 s but fell fairly rapidly into disrepute following criticisms by Wachter (1974) and Cain (1976). At about this time, sociologists, drawing on the work of Averitt (1968) of segmented labor market theorists, developed a theory of a dual or segmented economy. * The sociological theory is portrayed as corrective of the labor-supply-side and individualistic orientation of human capital and status attainment theory.

In this paper, we argue that neoclassical theory has been misrepresented in the literature on segmented economy and that tests designed to distinguish between "structural" and "neoclassical" models are inadequate for that task. Moreover, we maintain that dual labor market and dual economy theorists have concentrated on the aspects of the theory which represent the least significant departure from neoclassical economics. In fact, following a research heuristic of their own, neoclassical economists have developed elements of a segmented labor market model which is in many ways similar to the segmented economy theories found in sociology. We sketch this model and argue that the neoclassical model gives a precise meaning to the concept of dual or segmented labor markets but does not suggest that a classification system for job characteristics must rely on a single dimension. 


\section{Neoclassical Wage Determination *}

Sociological critics (e.g. Berg, 1981; Bibb \& Form, 1977; Horan, Beck \& Tolbert, 1980; Sorenson \& Kalleberg, 1981) have sometimes characterized the neoclassical model of wage determination as supply driven. According to this view, neoclassical economics ascribes productivity to the worker rather than to the job or to some combination of job and worker. Wage differences are said to be explained by individual characteristics rather than by the characteristics of the jobs the individuals hold. From this perspective, dual economy and dual labor market theory are perceived as reminding economists of their long-standing interest in demand as well as supply.

While these critics are certainly correct in their view that economists have paid excessive attention to the human capital model of earnings determination, neoclassical economists have developed quite sophisticated models in which individuals' productivities vary according to their job and have concerned themselves with the process whereby workers and jobs are matched. In developing such models, neoclassical economists clearly take account of both supply and demand. It is no more surprising to the neoclassical labor economist than to the dual labor market theorist that their graduate students will earn more as professional economists in consulting firms than as dishwashers in restaurants. 
In this section, we describe the neoclassical model of wage determination under pure competition when there is perfect information and when jobs and workers are heterogeneous. The model has a fairly extensive modern history; even if we ignore the obligatory reference to Adam Smith, the essentials of the model were developed in the early 1950s (Roy, 1950, 1951; Tinbergen, 1951, 1956). More recent work (Heckman \& Sedlacek, 1985; Rosen, 1974; Sattinger, 1979, 1980; Thaler \& Rosen, 1975) has built on this tradition.

In this model, the wage paid to workers in any particular job will depend on personal attributes which affect productivity and on characteristics of the job which affect its desirability. The relation between personal attributes and wages varies among jobs. Since information is assumed to be perfect, workers know what wage they will receive in any job if they have a certain combination of attributes and the job has a particular combination of characteristics. Certain attributes (e.g height) are, of course, not easily altered, but others such as education are somewhat under the control of the individual. It is these personal attributes and job characteristics which are the primary subject of economic analysis.

Let us consider an individual's decision about how much education to obtain. Since education is costly, individuals require higher earnings in order to compensate them for obtaining additional education. Figure 1 shows "indifference curves" for two different workers. The indifference curves represent combinations of schooling and earnings which leave that worker equally well off. Indifference curves which are higher and to the 
left are preferred since they represent higher earnings for a constant level of education (or the same earnings for less education). Of course, individuals care about aspects of a job other than the education it requires and the wages it pays. A myriad of factors such as location, safety, and job pace affect the way workers view jobs. Those readers who feel comfortable imagining tangencies of $n$-dimensional surfaces are encouraged to recognize the immediate applicability to the more general problem. For simplicity, we consider the case where jobs and workers have only two characteristics which for purposes of concreteness we term wages and education.

Figure 1 also shows the combinations of wages and schooling which are available to the individuals. Each individual chooses the point along the wage/schooling locus (or hedonic wage equation) which puts him or her on the highest indifference curve. By comparing the slopes of the two sets of indifference curves at points at which they are depicted as crossing, it can be seen that individual $B$ requires less compensation for obtaining education than does individual A. This may reflect any of several possibilities For example, perhaps B enjoys education more or has more financial resources with which to finance education, and therefore, relative to $\mathrm{A}$, chooses a combination of wages and schooling which involves higher wages and more schooling.

Figure 2 shows a similar decision for two different firms for a particular type of job. In each firm, workers' productivities depend on how much education they have received. However, education contributes more to productivity in firm B than in firm A. Figure 2 shows isoprofit 
curves for each firm, representing combinations of wages and education which leave the firm with the same profit. Isoprofit curves are more desirable to the firm as one moves down and to the right, representing combinations involving more education and lower wages. Firms have a decision problem which is analogous to that of workers. They recognize that they must pay higher wages in order to get workers with higher levels of education. Firms in which education increases productivity to a greater extent will be willing to spend more on hiring more educated workers. They choose the wage/education combination given by the point along the hedonic wage equation (HWE) which is just tangent to the isoprofit curve, representing the highest level of profit attainable by the firm.

The final element of the theory is the determination of the HWE. The HWE adjusts until the number of workers with each level of education is exactly equal to the number demanded. The result, shown in figure 3 , is that firms in which education is particularly valuable are matched with workers who require relatively little compensation for getting education. The HWE represents the market relation between education and wages.

The HWE is a standard wage equation of the type estimated in human capital models. We have derived it using a human capital theoretic explanation of the role of education which assumes that education increases productivity. However, we could equally have assumed that education serves as a signal of innate ability and that innate ability is more valuable in certain jobs than in others. The human capital interpretation is not essential to the model. In the light of 
sociological critiques of the human capital model, it is, however, important to note that the wage equation does not ignore "demand" factors. Instead the HWE is the market equilibrium locus resulting from the joint action of supply and demand when workers and jobs are heterogeneous. In fact, given the manner in which the model has been developed, it is not evident whether education should be considered a characteristic of the worker or of the job. It is, in fact, neither or both, depending on one's semantic choice, since it is a characteristic of the worker/job match. *

In particular, this model does not ignore marginal productivity theory. However, the theory's assumptions are hidden in the equilibrium requirement that the quantity supplied equal the quantity demanded. Firms simultaneously choose the number of workers to hire and the level of education. In equilibrium, the number of workers hired by the firm will be such that the wage exactly equals the value of the marginal product of the type of worker hired.

There are several limitations to the model which should be noted. In particular, it is a model of a perfectly competitive labor market. Thus it ignores the role of unions and monopsony. ${ }^{* *}$ Economists have generally used quite different models to describe wage setting in the presence of unions and do not apply the competitive model described here.

In addition, the model assumes perfect information which makes the assumption of perfect matching of workers and firms sensible. More realistically, the matching process should be modeled as one involving search and imperfect, costly information. However, it seems unlikely that 
allowing for search would alter the model significantly. A model can be constructed in which at each level of education, there is a distribution of wages available. In this model, when choosing their level of education, workers maximize their expected net wage (or expected utility) given optimal search behavior. Workers with low costs of schooling get more education, set higher reservation wages, and tend to end up in firms in which education contributes significantly to productivity. Thus while the matching process in a search model is not perfect, the broad outlines of the perfect information model continue to hold.

Simple search theory (dating at least from Stigler's (1962) seminal piece) allows workers to receive different wages for the same job; the extension to heterogeneous jobs is obvious. Models in which there is uncertainty about the quality of the job match have also been incorporated into the economic model (Jovanovic, 1979a\&b). It should, therefore, be evident from this description that the major departure of dual labor market theory from neoclassical theory is not that workers receive different wages depending on the job they obtain. There are, however, significant differences between the neoclassical and dual labor market models. These are addressed in the next section.

III. The Challenge of Segmented Labor Market Theories to Orthodox Theory Aside from a difference of methodology which has been emphasized by Woodbury (1979) and Piore (1983), the dual labor market models of the late 1960 s and early 1970 s departed from the standard neoclassical model in three significant ways. 
First, they introduced non-price rationing for good jobs. Unlike neoclassical labor economists, dual labor market theorists maintained that some individuals who were qualified for and wanted certain types of jobs at the going wage could not obtain them. In the standard economic model such people would bid down the wages in the desired jobs until supply equated demand -- the available jobs would be rationed by the price mechanism. In addition, difficulties of access were thought by dual labor market theorists to be systematic. Women, blacks, and other minorities faced barriers which inhibited them from obtaining desirable jobs.

A number of authors (Bluestone, 1970; Hodson \& Kaufman, 1982;

Kalleberg \& Sorenson, 1979; Leigh, 1976; Rosenberg, 1980; Schiller, 1977; Tolbert, 1982), including some dual labor market theorists, have interpreted the view that there were two sectors of the labor market with little or no mobility between them as a significant departure from human capital theory. However, lack of mobility between "sectors" is fully compatible with the neoclassical model as long as the initial worker-job matches are optimal. Further, mobility between sectors does not demonstrate the absence of non-price rationing.

A very simple neoclassical model in which workers acquire firm, occupation, industry or sector specific skills is consistent with no mobility whatsoever between firms, occupations, industries or sectors, respectively. Of course, more realistic models allow for some mobility, but limited mobility is a direct consequence of the existence of such skills. Thus much of the literature on internal labor markets and mobility chains is fully compatible with the neoclassical model. On the 
other hand, if qualified blacks had to work in bad jobs for a few years before obtaining good jobs but equally qualified whites could obtain good jobs immediately, there would be mobility between the sectors. In fact, we might find that blacks were more likely than whites to leave the "secondary" sector. However, the non-price rationing of good jobs would be inconsistent with standard models, despite the presence of mobility.

The second departure of dual labor market theories from neoclassical theory is the argument that the same product is often produced using two distinct technologies. While the assumptions of neoclassical economics do not preclude the existence of multiple solutions to the firm's maximization problem, in general, standard convexity assumptions provide structure to neoclassical models and ensure a unique maximum.

We will argue in section $V$ that both of these aspects of dual labor market theory have been incorporated into neoclassical economics by recent developments. These developments have occurred largely without explicit reference to dual labor market theory. We conclude that they were never really incompatible with neoclassical theory, although at the time they were viewed as significant departures.

Instead, we agree with Piore (1974) and Wachter (1974) that the major innovation of dual labor market theory was the attempt to make certain social-psychological qualities endogenous to the economic system. Thus Doeringer and Piore (1971) argue that the development of stable work habits depends on the type of job that workers obtain. In his later work $(1980 \mathrm{~b})$, Piore defines labor market sectors in terms of the types of reasoning they require and promote. Thus in the upper tier of the primary 
sector, we find a wide range of related work tasks; this enhances the worker's ability to achieve an abstract understanding of the work and is, thus, conducive to abstract understanding and learning. In the lower tier of the primary sector, the range of tasks is narrower and thus supports concrete more than abstract learning and understanding. Finally, work is organized in the secondary sector so that understanding is not required and, hence, inhibits abstract understanding. Dickens (1979) relates sector of employment to Kohlberg's stages of development and to Melvin Kohn's studies of work and personality.

It is important to note that Piore is not involved in psychological reductionism. Although the cognitive processes developed prior to employment, particularly in schools where training may depend on the social stratum from which the student is drawn, affect the initial placement of workers, the relation between job placement and cognitive processes is seen as reciprocal. The role of labor market stratum in determining cognitive processes is equally important. Thus the work is not anti-sociological but instead has natural links to sociological work on how social structure influences the way in which the individual comes to understand his place in society, a concern which has traditions dating at least to Marx, Durkheim and Simmel and which continues to interest modern researchers such as Thom (1983). Indeed, the issues addressed by Piore are also discussed in Durkheim's Division of Labor in Society.

Wachter suggests that endogenous tastes are not antithetical to neoclassical economics. We see little value in an extended debate on the philosophy of economics, but it appears to us that if neoclassical 
economics has any core tenets, they are that individuals have preferences which are exogenous to the economic system and are unchanging or only slowly changing over time and that they use available information efficiently to maximize their welfare given these preferences. Thus endogenous work habits and cognitive processes represent a significant departure from that model. It is unfortunate that this is also the aspect of dual labor market theory that has received the least attention. We have not discussed the internal labor market as a significant contribution of dual labor market theory. This is in part a matter of definition. While some of the most significant contributions to our understanding of internal labor markets are from dual labor market theorists (particularly, Doeringer \& Piore, 1971), we perceive their work as complementing rather than contradicting ongoing neoclassical work, a view shared by Cain (1976). Neoclassical economists recognized that the presence of firm-specific human capital created a bilateral monopoly with incentives for long term employment relations but an indeterminate wage profile over the course of that relation. Essentially any wage profile which gave both firm and worker incentives to maintain the employment relation and paid the (appropriately discounted) competitive wage over the life of the relation would be consistent with neoclassical theory. The internal labor market contribution considered how that indeterminacy is resolved. 


\section{The Sociological Response}

On the whole, the sociological literature on dual economy has not been concerned with the issues outlined above. To a certain degree, this reflects the fact that sociologists have drawn on a tradition derived from Averitt's (1968) work on dual economy and have relied only loosely on the dual labor market literature. With the possible exceptions of Bluestone (1970) and Edwards (1975), there is general agreement that while, the core or monopoly sector of the dual economy contains a preponderance of primary jobs, dual economy and dual labor markets represent different sources of division in the economy. Piore's work (1980a\&b) on these linkages seems to have been largely overlooked.

Thus the sociological literature on dual or segmented economy has taken as its starting point the existence of monopoly rents in the core sector. Wages in the monopoly sector may be higher because workers are able to capture part of these rents or because monopoly firms use their ability to pay to purchase worker cooperation. The need to assure worker loyalty is greater in large organizations and thus purchasing loyalty through higher wages is particularly useful in the monopoly sector. The literature on segmented economy (Kalleberg, Althauser \& Wallace, 1981) argues that the sources of worker power are more complex than suggested by dual economy theorists, but retains the emphasis on worker power. The dual and segmented economy models therefore explicitly reject the assumption of a perfectly competitive labor market which is crucial to the neoclassical model described in the previous section. In a perfectly competitive labor market, workers would be unable to capture rents which 
firms accrue in the product market. Moreover, "ability to pay" does not affect wage rates in a competitive market. Employers' ability to pay is irrelevant because competition among workers guarantees that all employers will pay the same wage for equivalent workers in jobs that are equally unpleasant. An employer who offered a wage below the market equilibrium wage would be unable to hire any workers. No employer would want to pay more (even if he or she could) since profits could be increased by paying only the going wage.

To an economist, the dual economy approach implies that there will be a queue (excess supply of workers) and thus non-price rationing for jobs in the monopoly sector since wages in that sector are above their market clearing level. Wages in the state sector are presumed to be patterned on monopoly sector wages; consequently there should also be a queue for state sector jobs as well. We do not wish to imply that the only prediction of the dual economy literature is that wages are higher in the core sector. On the contrary, the dual economy literature contains a number of hypotheses regarding the relation between worker attributes and sector of employment. For example, in the core sector, education is expected to play a larger role because of the greater reliance on credentials in large organizations. However, to a large extent these predictions can be interpreted as either resulting from the absence of market clearing, as in the case of discrimination (since employers can choose workers from the excess supply who correspond to the type of worker they desire), or to be hypotheses regarding where the firm will locate along the HWE and thus fully compatible with the neoclassical model. Thus, on the whole, again 
economic and sociological perspectives do not conflict but rather address different issues.

Thus from an economist's perspective the primary departure of segmented economy theory from neoclassical theory is the rejection of market clearing in the model of wage determination. Dual labor market theory also rejects market clearing; however, unlike most dual labor market models (for exceptions see Doeringer \& Piore, 1971; Piore 1975), dual economy theory provides a theoretical basis for the existence of queues and labor market segmentation which is derived from the ability of workers to capture monopoly rents.

On the other hand, dual economy theory has not taken up the two other departures from neoclassical theory which we discussed in the previous section. Unlike dual labor market theory, dual economy theory has tended to treat entire industries as being in the core or periphery and thus has not dealt with the use of differing technologies to produce the same output. Also, it has not addressed the relation between cognition, socialization and sector of employment with which dual labor market theory has been concerned.

Although the major departure from neoclassical theory of sociological theories of segmentation is the rejection of market clearing, the dual economy literature has concentrated on the issue of whether characteristics of the employer influence the wage received by the worker. A frequent practice in the segmented economy literature has been to test the model by regressing wages on firm and/or industry characteristics as well as worker characteristics (Hodson, 1984; 
Kalleberg, Wallace \& Althauser, 1981; Wallace \& Kalleberg, 1981). The fact that, in general, industry and/or firm characteristics enter the equation significantly is presented as evidence contradicting the human capital model.

There are two problems with this approach. First, the neoclassical model of section II implies that firm or industry characteristics will generally enter the wage equation with significant coefficients even when worker/job match characteristics or worker attributes are included, because inevitably not all characteristics are included and the functional form is only approximate. Secondly, if the dual market approach is correct, ordinary least squares is not a legitimate estimator for the wage equation. We discuss these problems in turn.

In the neoclassical model, it is perfectly legitimate to express the wage equation entirely in terms of worker characteristics, entirely in terms of firm characteristics or in terms of the worker/job match as in the HWE. To express the wage equation solely in terms of the worker's characteristics, note that from figures 1 and 3 , the level of education the worker obtains will depend entirely on his or her attributes. Therefore, instead of expressing wages as a function of worker/job match characteristics, it is possible to express the wage as a function of worker attributes. Similarly, wages can be expressed as a function of firm attributes. ${ }^{*}$ Thus, to reiterate, even if one interprets standard wage equations as expressing the wage solely in terms of worker attributes, it does not follow that they have ignored the importance of "demand." 
More significantly, since the model can be expressed as a function of any of the three types of characteristics, it is likely that when firm (or industry) characteristics are included in the equation along with worker characteristics that both will turn out to be significant. Since any functional form for the wage equation is inevitably an approximation to the "true" functional form, the error term in the wage equation with only worker characteristics will almost definitely be correlated with firm characteristics. Only if the wage equation were specified exactly and all relevant worker characteristics were measured perfectly would this not be true. Otherwise, firm or industry characteristics will be correlated with unmeasured characteristics such as job safety or the quality of worker hired.

Dickens and Katz $(1986,1987)$ address the issue of why there are significant inter-industry wage differences. They suggest three possibilities: 1) that the model outlined in section II is accurate but that there are inter-industry wage differentials resulting from temporary disequilibria, 2) that the model outlined in section II is accurate and that inter-industry wage differentials reflect unmeasured job match characteristics and 3 ) that the neoclassical model outlined in section II is inaccurate. They provide evidence that inter-industry wage differentials have persisted over extended periods of time and thus conclude that the temporary disequilibrium hypothesis can be rejected. They also marshall evidence that inter-industry differentials persist even after careful statistical controls for a large number of job match characteristics, and that inter-industry differentials are strongly 
correlated across occupations. Thus, they conclude that the neoclassical the model outlined in section II is probably inaccurate.

However, as noted above, the standard neoclassical model implies that firm or industry characteristics enter the wage equation containing individual characteristics because they are correlated with the error term. In contrast, the dual economy model suggests that these characteristics belong in the equation in their own right. Therefore, this conclusion ultimately rests either on conjectures about how large inter-industry wage differentials can be or on auxiliary hypotheses such as how correlated over time and across occupations and nations inter-industry wage differentials should be. Thus including industry or firm characteristics in the wage equation at best provides a weak test of the neoclassical model.

Moreover, if the segmented market model is correct, it is not legitimate to interpret the OLS coefficients of a single wage equation with industry dummies or characteristics as measuring the amount of monopoly rents captured by workers. As noted above, the dual economy hypothesis implies that there are queues for good jobs. Since there is an excess supply of workers for these jobs, firms will choose the "best" available workers from the queue. These workers will be those whose wages are unusually low given their productivity. Since it is inevitable that we do not measure all determinants of wages, the expected value of the contribution of unmeasured characteristics to the wage (in other words, the error term) in those jobs is negative rather than zero as required for ordinary least squares. Thus, in general, ordinary least squares will 
overestimate the importance of industry dummies or characteristics.

This criticism is, if anything, more compelling when applied to tests which have divided the sample into sectors and tested for the existence of separate equations explaining the determination of wages for each sector (Beck, Horan \& Tolbert, 1978; Hodson, 1978, 1984; Horan, Beck \& Tolbert, 1980; Osterman, 1975; Zucker \& Rosenstein, 1981). The endogeneity of sector of employment is particularly important because, as Cain (1976) has pointed out, if workers are divided into two sectors, a large sector composed mainly of workers with high wages and a small sector composed mainly of workers with low wages, we will estimate that the returns to education and experience are lower in the "low wage sector" even if in fact there are not two distinct sectors. The estimated return to education will be biased downwards in both sectors by the truncation of the wage, but the bias will be more serious in the smaller sector since the fraction of "missing" observations is larger. This statistical problem can be avoided only by explicitly modeling the assignment of workers to sectors. There is an extensive literature on consistent estimation of models with this sort of selection problem. (see Maddala, 1983, for an excellent review.)

A second difficulty arises because, with the exception of Dickens and Lang (1985a\&b, 1986, 1987), al1 estimates of sectoral models assume that the sector of employment is known. Yet as Zucker and Rosenstein (1981) make clear, the correlations among classification schemes that divide industries into a core and periphery sector are relatively weak, ranging from 578 to 838 agreement for the four taxonomies they study. The degree 
of disagreement is striking when one considers that if each study had assigned people to sectors randomly but in the same proportions as in the actual studies, the level of agreement would have ranged from 408 to 508 .

Without doubt, part of the disagreement is due to underlying theoretical differences. However, much of the disagreement simply reflects the difficulties entailed in moving from the theoretical conception to the empirical application. It simply is not possible to use industry of employment to establish sector of employment with any degree of certainty.

The appropriate solution is to model sector of employment as unknown a priori and to let the estimation technique determine the sector of employment. The appropriate statistical technique is described in Dickens and Lang (1985a) -. "endogenous switching with unknown regimes." To estimate this model the research specifies two or more equations which describe the wage determination process in each sector as a function of human capital and other variables. The researcher also specifies an equation describing the process by which people are assigned to the two sectors as a function of human capital and ascriptive criteria. The model is estimated by maximum likelihood. In effect, the model assigns a probability of being in each sector to each person on the basis of ascriptive and human capital variables. Simultaneously, it estimates the return to human capital and other variables in each sector. This "endogenous switching model with unknown regimes" stands at the opposite end of the spectrum from the "exogenous switching models with known regimes" which have been used in the dual economy literature. The latter 
assume that industry of employment provides complete information about sector of employment while the former makes no use of industry information to assign workers to sectors. (If one wished to compromise between the two approaches, one could modify the technique developed by Dickens and Lang to take account of industry information without assuming that sector of employment is known perfectly.)

In sum, the segmented economy literature distinguishes itself from the neoclassical model primarily by rejecting the assumption that wages adjust to clear labor markets. As will be discussed below, there has been a resurgence of interest in such models in neoclassical economics as well. However, while both economists and sociologists have concerned themselves with testing the segmented markets model by establishing whether firm or industry characteristics enter a wage equation significantly, this does not really address the issue of market clearing. Moreover, the estimation techniques used in these "tests" are inappropriate for the dual market model.

\section{Testing for Queues}

Since both the dual labor market and dual economy models differentiate themselves from the neoclassical model by rejecting the existence of market clearing, the most direct way to distinguish between segmented market models and the standard neoclassical model is to test for the existence of queues. 
The most straightforward manner in which to consider whether or not there are queues for jobs is to examine the effect of inter-industry wage differentials on quit rates. If workers in high wage industries are, in fact, receiving rents, we would expect them to have lower quit rates. This prediction is confirmed by a number of studies. However, interpretation of this result is hindered by an inadequate theory of why quits occur. Moreover, if high ability workers tend to invest more heavily in firm specific capital, they will simultaneously have higher wages and lower quit rates.

Farber (1983) presents the most sophisticated approach to studying queues in his examination of queues for union jobs. He points out that it is necessary to model the process whereby individuals are allocated to each sector. Allocation is the outcome of two decisions. First, workers must decide whether or not to seek union employment. Since the nonunion sector is assumed to be competitive, those workers who desire nonunion jobs at the going wage rate enter the nonunion sector. However, not all workers who desire union jobs obtain them. Instead, the union wage premium results in a queue (excess supply of workers) for union jobs. Workers only obtain union jobs if an employer chooses them from the queue. Thus the probability of being allocated to the union sector is the probability of wanting a union job multiplied by the probability of obtaining a union job given that the worker desires one. If there is not an excess supply of labor for union jobs, the latter probability is one, and the model reduces to one in which only the probability of wanting a union job equation needs to be estimated. Thus, the no queue model is 
nested in the queue model, and it is possible to test for the existence of queues. Farber's work is facilitated by the presence of a measure of whether or not the workers desire union jobs.*

Dickens and Lang (1985a,b, 1986), use a somewhat different approach in the context of a dual labor market model. They point out that if workers were free to choose their sector of employment, they would tend to enter the sector in which their earnings, adjusted for the value of nonwage characteristics of employment, were highest. Using the endogenous switching model with unknown regimes discussed above, they find that for an equal wage differential between the sectors, nonwhites are more likely to be employed in the secondary sector. There are two possible conclusions -- either nonwhites place a lower value on the nonwage characteristics of the primary sector or nonwhites find it more difficult to obtain primary employment. Auxiliary evidence ${ }^{* *}$ tends to contradict the first conclusion. Therefore, it appears that nonwhites face nonprice discrimination which implies the absence of market clearing.

\section{Notes for A Neoclassical Model of Labor Market Stratification}

We have presented evidence in support of the view that there is an excess supply of labor for certain types of jobs. Since one of the major departures of segmented market theory from earlier neoclassical theory is the existence of queues, it is important to consider the extent to which queues are compatible with more recent developments in neoclassical theory. The major conclusion of this section will be that recent neoclassical theorists have produced the elements of a model which, on 
those topics which have traditionally concerned neoclassical economists, captures the major departures of dual labor market theory from neoclassical theory. In addition, this theory helps clarify the relation between dual economy theory and dual labor market theory. Moreover, there is considerable convergence between the neoclassical and sociological models. The major difference is that, in the recent neoclassical theory, nonmeritocratic stratification can occur even when all markets are competitive.

For the last decade, some of the most important work in economics has concerned itself with developing a microeconomic foundation for macroeconomics. Within economics there has been a split between a microeconomic model which assumes general equilibrium with market clearing and a Keynesian macroeconomic model which many would argue is based on the failure of market clearing. Two schools of thought have arisen in response to this dichotomy. One of these has attempted to explain macroeconomic phenomena in terms of a market clearing model, and the other has attempted to develop microeconomic models to explain the absence of market clearing.*

The latter school has developed a number of related models which fall under the general rubric of efficiency wage models. In order to describe efficiency wage models, it is easiest to make the simplifying assumption that all workers and jobs are homogeneous (though this assumption is not necessary to the models). In this model, each firm chooses the amount of labor it employs in order to maximize profits. In the standard model, the derivative of profits with respect to the wage is just the negative of the 
amount of labor employed. In other words, as wages increase, profits fall. Therefore, the firm would like to set the wage as low as possible, and it would never pay more than the minimum necessary to obtain the quantity (and in a more general model, quality) of workers it desires.

Under the various efficiency wage models, raising wages can increase profits. In most efficiency wage models this results from the fact that output depends on the wage. As a consequence, in efficiency wage models, firms do not necessarily choose the lowest possible wage; instead they choose the wage which maximizes their profits. If the wage which maximizes profits is above the market clearing wage, some workers will be unemployed. In the standard model, unemployed workers would bid down any wages above the market clearing level. However, in efficiency wage models, since the wage has been chosen to maximize profits, lowering the wage would actually lower profits. Consequently, there can be an excess supply of labor.

Katz (1986) and Yellen (1984) provide extensive reviews of the various efficiency wage models. We provide only a brief summary here. In most efficiency wage models, output is assumed to depend on the wage and not just on the quantity of labor employed as in more standard models. Wages may affect output in a number of ways - - through worker morale (Solow, 1979a; Akerlof, 1982), through differences in the quality of workers hired that are unobservable by the firm (Weiss, 1980), by reducing quits, or by reducing shirking, stealing and cheating (Bowles, 1985; Calvo, 1979; Shapiro \& Stiglitz, 1984; Stoft, 1982). In the models in which higher wages reduce the probability of workers' cheating, shirking 
or quitting, the higher wage makes it costly for workers to lose their jobs and thus provides a disincentive to behavior which might cause them to be fired. In the morale models the higher wage might be thought of as changing workers' preferences, but in the other models, preferences are clearly constant, and workers change their behavior only because incentives have been modified. The latter fit more easily into the neoclassical paradigm of profit maximizing firms and utility maximizing workers with constant preferences.

The motivations for paying high wages are similar to those found in the segmented economy literature. However, it should be noted that none of the models above relies on the existence of monopoly rents or "ability to pay" that is central to the segmented economy literature. Instead, in most efficiency wage models, the queues exist despite pure competition in the product market. One version of the efficiency wage model, however, is quite close to the most prevalent model in the dual economy literature. Dickens (1986) argues that firms may pay higher wages in order to deter workers from taking collective action such as forming a union. The need to pay union-deterring wages is greatest when the potential rents captured by the union are large either due to the firm's monopoly power in the product market or due to the presence of fixed capital.

Although the efficiency wage models were developed to explain what many economists perceive as the failure of the wage to adjust to clear the labor market, they have obvious application to the development of a formal neoclassical model of labor market segmentation. If the costs of monitoring workers or the costs of worker malfeasance differ among 
industries, the wage levels which maximize profits will differ among industries. If there is a set of firms which pay efficiency wages and a set of firms which do not pay efficiency wages, then there will be two sectors of the labor market. One will have high wages and an excess supply of labor. The other will have low wages and behave according to the standard competitive model. Such models are developed informally in Dickens and Lang (1984) and Yellen (1984) and formally in Jones (1985) and Bulow and Summers (1986).

The above discussion suggests a clear relation between the dual economy and dual labor market classifications. The primary sector consists of all jobs for which there is structural and equilibrium excess supply even in equilibrium. Thus the queues are structural rather than transitory. Jobs in the monopoly or core sector tend to be in the primary sector because, in general, the existence of a large amount of fixed capital or monopoly rents is conducive to the formation of a union. In addition, some versions of the efficiency wage model imply that firms which earn rents will pay high wages because workers' conceptions of fair pay depends on the ability of firms to pay. Also such firms may pay high wages to deter unionization since the potential gains from unionization are greater in the presence of rents. Furthermore, monopoly sector firms tend to have high capital/labor ratios. Many efficiency wage models suggest that firms with high capital/labor ratios will pay high wages since the need to avoid shirking, abseenteeism and quits is greatest in the presence of large quantities of fixed capital. Thus monopoly sector firms tend to pay efficiency or union-deterring wages. However, some 
firms which are not in the monopoly sector may find it beneficial to pay efficiency wages which exceed market clearing levels to at least some of their workers. Consequently, the primary labor market is considerably more extensive than the monopoly sector.

Unfortunately, the efficiency wage model described above does not provide a completely satisfactory neoclassical model of dual labor markets. The major difficulty is that it suggests that unemployment consists of people queuing for jobs in the primary labor market. Since primary jobs tend to be stable, this contradicts evidence that much unemployment consists of frequent long spells of unemployment interrupted by short spells of employment and certainly conflicts with a perspective designed to explain persistent poverty and unemployment among certain disadvantaged groups.

The answer to this problem lies in a model which is described informally in Piore (1975) and developed independently in a neoclassical model of contestable markets under uncertainty by Appelbaum and Lim (1985). In that model, there is uncertain demand for industry output. Output may be produced using either of two technologies, a low variable-cost/high fixed-cost technology which requires investment prior to the realization of the state of demand or a high variable-cost/low fixed-cost technology which does not require prior investment. Firms will invest in the low variable-cost technology in order to satisfy relatively certain demand. When demand is high, they will produce additional output using the high variable-cost technology. The proportion of demand which is satisfied using the low variable-cost technology will depend on the 
relative costs of the two technologies, the cost of storing the good and on the variability of demand. If demand is perfectly stable or if the high variable-cost technology is much more expensive than the low variable-cost technology and the good is storable, all output will be produced using the low variable-cost technology. On the other hand, if demand is highly unstable, the good is not storable and the cost difference is small, almost all demand will be produced using the high variable-cost technology. In most industries some output will be produced using the low variable-cost technology, but this output will be supplemented in boom periods through the use of the high variable-cost technology.

It is worth noting that it is possible that high demand/ high variable-cost technology production may take place in the same firms that also use the low variable-cost technology, or in firms that "specialize" in high variable-cost technology. For example, consider an old-fashioned luncheonette which sells ice cream. For the luncheonette the marginal cost of supplying the relatively stable day to day demand for ice cream is low. However, every once in a while, there is an unusually hot day and the demand for ice cream increases. The increased demand for ice cream might be accommodated by setting up an additional stand outside the luncheonette or push cart operators who sell hot chestnuts in the winter might rapidly convert their carts to handle ice cream. Factors such as the nature of the technology and access to short term labor markets and ice cream suppliers would determine whether one or both of these solutions would be used. 
The Appelbaum/Lim contestable markets model provides a very different model of economic dualism than the one based on a division of firms into those in the monopoly and competitive sectors. Moreover, as Piore (1975) argued, it is clear that not only can different firms within an industry use different technologies, but even within firms, different technologies may be used to produce the same output.

It is easy to see why primary sector jobs would tend to be located in firms using low variable-cost technologies. As Bulow and Summers (1986) point out, when jobs become unstable, the wage required to deter cheating increases since workers expect to receive that wage over a shorter period of time. When the efficiency wage required to avoid worker malfeasance becomes sufficiently large, firms will prefer to use other means such as direct monitoring of workers' behavior. Thus firms facing stable demand will tend to pay efficiency wages while firms facing unstable demand will tend to use direct monitoring. This link between sector and method of worker regulation is reminiscent of Edwards (1979).

of course, the link between stable demand and primary labor market jobs will not be perfect. In some stable jobs, the cost of direct monitoring will be sufficiently low that it will be preferable to paying efficiency wages, while, in some unstable jobs, the cost of monitoring may be sufficiently high to justify the use of efficiency wages despite the instability. Thus while job stability, the use of low variable-cost technology and high wages will tend to be linked, none of the pairwise correlations will be perfect. 
In addition, economic theory suggests that a number of other factors are likely to be correlated with job stability, including investment in on-the-job training and the use of pensions and job ladders. Thus there are a number of job characteristics which we would expect to be correlated.

In this way, the neoclassical approach to dual labor market theory casts light on the usefulness of factor-analytic approaches to testing the model. A number of papers (Buchele, 1976; Gordon, 1971; Hodson \& Kaufman, 1981; Horan, Tolbert \& Beck, 1981; Kaufman, Hodson \& Fligstein, 1981; Oster, 1979; Tolbert, Horan \& Beck, 1980) have interpreted dual economy theory or dual labor market theory as maintaining that all jobs can be classified on the basis of a single bimodal factor. They have either attempted to test these models by techniques such as factor analyzing job or industry characteristics to see whether they can be classified using a single bimodally distributed factor, or have criticized dual economy theory for not recognizing the greater dimensionality of segmentation (Kalleberg, Wallace \& Althauser, 1981; Wallace \& Kalleberg, 1981). In the light of the neoclassical model, this approach is generally misguided. Nothing in the model suggests that a single factor should be sufficient to classify jobs. It does suggest that one important factor should link wages, stability and technology.

However, dual labor market theory does not imply that the dual labor market is the only basis on which jobs can be classified. For instance, if in the list of job characteristics we were to include outdoor work in winter, western region, commuting distance, commuting method, whether or 
not most workers in the firm were born in the state or unionized, a factor analysis would probably uncover an additional factor which might be termed "sun belt." The presence of this second factor would in no way disprove dual labor market theory. The model implies that certain characteristics should be correlated not that no other characteristics are.

One of the weaknesses of dual labor market theory has been that it has generally been presented as a classification scheme designed to describe certain empirical regularities. Without an underlying theoretical base, it is difficult to maintain that one classification scheme is superior to another. Thus, if a study finds that the variation in wages that can be explained by a four or sixteen or sixty-four sector model is significantly greater than that which can be achieved with a two sector model, it is tempting to conclude that the dual labor market model has been rejected. Drawing this conclusion is inappropriate for two reasons - first, because dual labor market theory does not suggest that the only determinant of wages is sector of employment and, secondly, because dual labor market theory should not be regarded principally as a classification system.

\section{Some Concluding Remarks}

Although dual labor market theory has been largely atheoretical, the neoclassical model we sketched in the last section is not the first attempt to provide it with a theoretical underpinning. In fact, we perceive that model as being a relatively faithful neoclassical rendering of ideas presented by Doeringer and Piore (1971) and Piore (1975, 
$1980 \mathrm{a} \& b)$. The fact that it is possible to present a neoclassical version of these ideas suggests that they were never all that incompatible with neoclassical economics.

Similarly, we believe that dual economy theory should also be perceived as being compatible with neoclassical economics. The sociological work in this area addresses the problems of eliciting worker effort that, from a different perspective, are the concern of efficiency wage and agency (Becker \& Stigler, 1974; Lazear, 1979, 1981) models in economics. There is clear potential for cross-fertilization of the economic and organizational (e.g. Baron \& Bielby 1980, 1982, 1984; Stolzenberg, 1978) perspectives. From an economic perspective, the sociological literature has paid undue attention to the role of monopoly rents and insufficient to other economic conditions which foster or inhibit the growth of different administrative mechanisms.

Nevertheless, in the light of our analysis, we cannot avoid a certain disappointment that sociologists have not concerned themselves more with the most significant departure of dual labor market theory from neoclassical economics - the attempt to incorporate social-psychological feedback into the system. Whether a model which dropped the assumption of perfect rationality to incorporate the Piagetian concepts of Piore (1980b) or a model which allowed tastes to be endogenous would still be neoclassical is largely a matter of definition. We are, however, inclined to agree with Piore (1974) that exogeneity of tastes and perfect rationality are essential to the neoclassical model and that dropping these assumptions would give rise to a model which differed significantly 
from existing theory. In neoclassical economics, the individual is a completely formed entity from birth. His or her utility function is exogenous to the economic system, and since all individuals are fully rational with unlimited cognitive capacity, cognition is independent of the organization of work. It is in this area that the dual labor market model presents the greatest challenge to neoclassical economics. Moreover, sociologists have more training and experience with this type of model. Perhaps sociologists have neglected dual labor market theory's tentative steps towards integrating these sociological notions with labor market theory because of the weakness of the economists' efforts in this direction. We expect that this is one direction of inquiry in which sociologists could make substantial contributions to theories of labor markets. 


\section{FOOTNOTES}

cover page

* We are grateful to Sam Gilmore, Shulamit Kahn, Ken Small, David Smith and Gary Thom for helpful comments and criticisms and to the National Science Foundation for research support under grant number SES8606139. Any errors of fact or interpretation are, of course, entirely our responsibility.

page 1

* Throughout this paper we use the following nomenclature. We use "dual or segmented labor markets" when we refer to the economic literature, "dual or segmented economy" when we refer to the sociological literature and "dual or segmented markets" when we refer to both literatures simultaneously. Neoclassical economists should be viewed as distinct from the Marxists and institutionalists who, together, comprise the schools of economic thought from which dual labor market theory developed.

page 2

* This section is based heavily on Kahn and Lang (1986). A related analysis of the market for occupational safety is described in Kahn (1985).

page 5

* More formally, the firm chooses the number of workers to hire and the level of education to require of them in order to maximize profits given by 


$$
\text { profits }=f(L, E, u)-w(E) L
$$

where without loss of generality the price of output has been normalized to equal $1, f$ is the production function net of any capital costs, $L$ is the number of workers hired, $E$ is their level of education, $w$ is the wage they receive and $u$ is a parameter measuring the contribution of education to productivity in the firm.

Similarly, workers choose their level of education in order to maximize their appropriately discounted lifetime earnings net of education costs

$$
\text { net earnings }=w(E)-c(E, e)
$$

where $c$ is the appropriately amortized cost of education and $e$ represents the ease of obtaining schooling for the individual. It can be shown that the firm's demand depends on $u$ and the slope of the HWE (the w function) and, that similarly, the level of education chosen by the worker depends on $e$ and the slope of the HWE:

$$
E^{d}=E^{d}\left(w^{\prime}, u\right)
$$

$$
E^{S}=E^{S}\left(w^{\prime}, e\right)
$$

where superscripts denote supply and demand, and $w^{\prime}$, the slope of the HWE, serves the role of price in standard supply or demand equations. 
The competitive market matches workers with high values of $\mathrm{e}$ with firms with high values of $u$. This matching process can be described by a function relating e to $u$ :

$$
e=f(u) \quad f^{\prime}>0 .
$$

To derive the HWE, we proceed as follows - - first, solve (3) and (4) for $u$ and $e$ as functions of $w^{\prime}$ and $E$ :

$$
e=e\left(w^{\prime}, E\right)
$$

$$
u=u\left(w^{\prime}, E\right)
$$

The next step is to substitute (6) and (7) into (5) to obtain

$$
e\left(w^{\prime}, E\right)=f\left(u\left(w^{\prime}, E\right)\right)
$$

and then solve for $w^{\prime}$ as a function of $E$

$$
w^{\prime}=w^{\prime}(E) \text {. }
$$

Finally, (9) can be integrated to obtain the hedonic wage equation

$$
w=w(E) \text {. }
$$


page 6

* The fact that the wage equation can be interpreted as the equilibrium outcome of the interaction of supply and demand does not mean that this fact was clearly recognized in the seminal work of Becker (1971) and Mincer (1974). To the extent that the development of the human capital model ignored demand factors, the sociological criticism of the theoretical work is justified.

page 6 ** Monopsony refers to a market with only one buyer. In a labor market a monopsony exists when one firm or a group of firms acting together are the sole source of employment for a particular group of workers.

page 15

* More formally, from equation (9), $w^{\prime}$ is a function of $E$. Therefore, it is possible to substitute for $w^{\prime}$ in the demand equation and solve for $E$ as a function of $e$. Kahn and Lang (1986) refer to this as the quasi-reduced form demand equation. Having derived $\mathrm{E}$ as a function of $e$, it is possible to substitute for $E$ in the HWE and derive $w$ as a function of e. By a similar process, it is possible to express the wage solely in terms of firm characteristics.

page 22

* Nevertheless, Abowd and Farber (1982) demonstrate that it is possible to test for the existence of queues even in the absence of such a measure. 
page 22

** Blacks are more likely to support unions in representation elections (Farber \& Saks, 1980; Dickens, 1983), are less likely to quit a job (Viscusi, 1979) and have greater demand for occupational safety than equivalent whites (Kahn, 1983). Primary jobs are generally believed to be more heavily unionized, provide more stable employment and to be safer than secondary jobs. Thus, it is doubtful that blacks prefer the nonpecuniary features of secondary employment to a greater extent than whites.

page 23

* See Solow (1979b) for a discussion of this debate. 


\section{$\underline{\text { References }}$}

Abowd, John. M., and Henry S. Farber. 1982. "Job Queues and the Union Status of Workers." Industrial and Labor Relations Review 35:354-67. Akerlof, George A. 1982. "Labor Contracts as Partial Gift Exchange." Quarterly Journal of Economics 87:543-569. Appelbaum, Eli, and Chin Lim. 1985. "Contestable Markets Under Uncertainty." Rand Journal of Economics $16: 28-40$.

Averitt, Robert T. 1968. The Dual Economy. New York: Norton \& Co. Baron, James N., and William T. Bielby. 1980. "Bringing the Firms Back In: Stratification, Segmentation, and the Organization of Work." American Sociological Review 45:737-765.

Baron, James N., and William T. Bielby. 1982. "Workers and Machines: Dimensions and Determinants of Technical Relations in the Workplace." American Sociological Review 47:175-188.

Baron, James N., and William T. Bielby. 1984. "The Organization of Work in a Segmented Economy." American Sociological Review 49:454-473.

Beck, E.M., Patrick M. Horan, and Charles M. Tolbert. 1978. "Stratification in a Dual Economy: A Sectoral Model of Earnings Determination." American Sociological Review 43:704-720.

Becker, Gary S. and George J. Stigler. 1974. "Law Enforcement, Malfeasance, and the Compensation of Enforcers." Journal of Legal Studies $3: 1-18$.

Berg, Ivar. 1981. "Sociological and Institutional Perspectives on Labor Markets." Pp. 1-7 in Sociological Perspectives on Labor Markets, edited by Ivar Berg. New York: Academic Press. 
Bibb, Robert, and William H. Form. 1977. "The Effects of Industrial, Occupational and Sex Stratification on Wages in Blue-Collar Markets." Social Forces 55:974-996.

Bluestone, Barry. 1970. "The Tripartite Economy: Labor Markets and the Working Poor." Poverty and Human Resources Abstracts 5:15-35.

Bowles, Samue1. 1985. "The Production Process in a Competitive Economy: Walrasian, Neo-Hobbesian and Marxian Models." American Economic Review $75: 16-36$.

Buchele, Robert. 1976a. "Jobs and Workers: A Labor Market Segmentation Perspective on the Work Experience of Young Men." unpublished doctoral dissertation, Harvard University.

Bulow, Jeremy I., and Lawrence H. Summers. 1986. "A Theory of Dual Labor Markets with Application to Industrial Policy, Discrimination and Keynesian Unemployment," Journal of Labor Economics 4:376-414.

Cain, Glenn. 1976. "The Challenge of Segmented Labor Market Theories to Orthodox Theory." Journal of Economic Literature 14:1215-1257. Calvo, Guillermo. 1979. "Quasi-Walrasian Theories of Unemployment." American Economic Review 69:102-107.

Dickens, William T. 1979. "Work and Personality: A Structural Interpretation of the Class-Values Relation."

Dickens, William T. 1983. "The Effect of Company Campaigns on Certification Elections: Law and Reality Once Again." Industrial and Labor Relations Review 36:560575.

Dickens, William T. 1986. "Wages, Employment and the Threat of Collective Action by Workers," NBER Working Paper No. 1856. 
Dickens, William T., and Lawrence Katz. 1986. "Occupational and Industry Wage Structures and Modern Theories of Wage Determination," mimeo. Dickens, William T., and Lawrence Katz. 1987. "Industry Characteristics and Interindustry Wage Differences." Pp. 48-89 in Unemployment and the Structure of Labor Markets, edited by Kevin Lang and Jonathan $S$. Leonard. Oxford: Basil Blackwell.

Dickens, William T., and Kevin Lang. 1985a. "A Test of Dual Labor Market Theory." American Economic Review 75:792-805. (previously NBER working paper no. 1314, 1984).

Dickens, William T., and Kevin Lang. 1985b. "Testing Dual Labor Market Theory: A Reconsideration of the Evidence," NBER working paper No. 1670 .

Dickens, William T., and Kevin Lang. 1986. "Labor Market Segmentation and the Union Wage Premium," NBER working paper No. 1883.

Dickens, William T., and Kevin Lang. 1987. "Where Have All the Good Jobs Gone? Deindustrialization and Theories of Dual Labor Markets," Pp. 90-102 in Unemployment and the Structure of Labor Markets, edited by Kevin Lang and Jonathan S. Leonard. Oxford:Basil Blackwell.

Doeringer, Peter B., and Michael J. Piore. 1971. Internal Labor Markets and Manpower Analysis. Lexington, Mass.: D.C. Heath.

Edwards, Richard. 1975. "The Social Relations of Production in the Firm and Labor Market Structure." Pp. 3-26 in Labor Market Segmentation, edited by Edwards, Richard, Michael Reich,, and David M. Gordon. Lexington, MA: D.C. Heath.

Edwards, Richard. 1979. Contested Terrain. New York: Basic Books. 
Farber, Henry S. 1983. "The Determination of the Union Status of Workers." Econometrica $51: 1417-38$.

Farber, Henry S., and Daniel H. Saks. 1980. "Why Workers Want Unions: The Role of Relative Wages and Job Characteristics." Journal of Political Economy $88: 346-369$.

Gordon, David M. 1971. "Class, Productivity and the Ghetto." unpublished doctoral dissertation, Harvard University.

Heckman, James J., and Guilherme Sedlacek. 1985. "Heterogeneity, Aggregation, and Market Wage Functions: An Empirical Model of Self-Selection in the Labor Market." Journal of Political Economy $93: 1077-1125$.

Hodson, Randy. 1978. "Labor in the Monopoly, Competitive and State Sectors of Production." Politics and Society $8: 429-480$.

Hodson, Randy. 1984. "Companies, Industries, and the Measurement of Economic Segmentation." American Sociological Review 49:335-348. Hodson, Randy, and Robert L. Kaufman. 1981. "Circularity in the Dual Economy: Comment on Tolbert, Horan, and Beck." American Journal of Sociology $86: 881-887$.

Hodson, Randy, and Robert L. Kaufman. 1982. "Economic Dualism: A Critical Review." American Sociological Review 47:727-739.

Horan, Patrick M., E. M. Beck, and Charles M. Tolbert. 1980. "The Market Homogeneity Assumption: On the Theoretical Foundations of Empirical Knowledge." Social Science Quarterly 61:278-291.

Horan, Patrick M., Charles M. Tolbert, and E.M. Beck. 1981. "The Circle Has No Close." American Journal of Sociology 86:887-894. 
Jones, Stephen R.G. 1985. "Minimum Wage Legislation in a Dual Market." mimeo, University of British Columbia.

Jovanovic, Boyan. 1979a. "Job Matching and the Theory of Turnover." Journal of Political Economy 87:972-991.

Jovanovic, Boyan. 1979b. "Firm-specific Capital and Turnover." Journal of Political Economy 87:1246-1260.

Kahn, Shulamit. 1983. "Occupational Safety and Worker Preferences." unpublished doctoral dissertation, Massachusetts Institute of Technology .

Kahn, Shulamit. 1985. "Economists' Evaluation of the Value of Life," Proceedings of the National Science Foundation.

Kahn, Shulamit. 1986. "Economic Estimates of the Value of Life."

Kahn, Shulamit, and Kevin Lang. 1986. "Structural Hedonic Systems: Efficient Estimation and Specification Tests." mimeo, Irvine.

Kalleberg, Arne, and Aage B. Sorenson. 1979. "The Sociology of Labor Markets." Annual Review of Sociology 5:351-379.

Kalleberg, Arne, Michael Wallace, and Robert P. Althauser. 1981. "Economic Segmentation, Worker Power, and Income Inequality." American Journal of Sociology $87: 651-83$.

Katz, Lawrence F. 1986. "Efficiency Wage Theories: A Partial Evaluation," in NBER Macroeconomics Annual, 1986, Cambridge, MA: MIT.

Kaufman, Robert L., Randy Hodson, and Neil D. Fligstein. 1981. "Defrocking Dualism: A New Approach to Defining Industrial Sectors." Social Science Research 10:1-31. 
Lazear, Edward. 1979. "Why is there Mandatory Retirement?" Journal of Political Economy $87: 261-284$.

Lazear, Edward. 1981. "Agency, Earnings Profiles, Productivity, and Hours Restrictions." American Economic Review 71:606-620.

Leigh, Duane. 1976. "Occupational Advancement in the Late 1960s: An Indirect Test of the Dual Labor Market Hypothesis." Journal of Human Resources 11:155-171.

Maddala, G. S. 1983. Limited-Dependent and Qualitative Variables in Econometrics, New York: Cambridge University Press. Oster, Gerry. 1979. "A Factor Analytic Test of the Theory of the Dual Economy." Review of Economics and Statistics $61: 33-51$.

Osterman, Paul. "An Empirical Study of Labor Market Segmentation." Industrial and Labor Relations Review 28:508-523.

Piore, Michael J. 1974. "Comment on Wachter." Brookings Papers on Economic Activity $3: 684-688$.

Piore, Michael J. 1975. "Notes for a Theory of Labor Market Stratification" Pp. 129-150 in Labor Market Segmentation, edited by Richard C. Edwards, Michael Reich, and David M. Gordon. Lexington, MA: D.C. Heath.

Piore, Michael J. 1980a. "Dualism as a Response to Flux and Uncertainty." Pp. 23-54 in Dualism and Discontinuity in Industrial Societies, edited by Suzanne Berger and Michael J. Piore. New York: Cambridge University Press. 
Piore, Michael J. 1980b. "The Technological Foundations of Dualism," Pp. 55-81 in Dualism and Discontinuity in Industrial Societies, edited by Suzanne Berger and Michael J. Piore. New York: Cambridge University Press.

Piore, Michael J. 1983. "Labor Market Segmentation: To What Paradigm Does It Belong?" American Economic Review Papers and Proceedings $73: 249-253$.

Rosen, Sherwin. 1974. "Hedonic Prices and Implicit Markets: Product Differentiation in Pure Competition." Journal of Political Economy $82: 34-55$.

Rosenberg, Samue1. 1980. "Male Occupational Standing and the Dual Labor Market." Industrial Relations 19:34-49.

Roy, A. D. 1950. "The Distribution of Earnings and of Individual Output." Economic Journal 60:135-146.

Roy, A. D. 1951. "Some Thoughts on the Distribution of Earnings." Oxford Economic Papers 3:135-146.

Sattinger, Michael. 1979. "Differential Rents and the Distribution of Earnings." Oxford Economic Papers 31:60-71.

Sattinger, Michae1. 1980. Capital and the Distribution of Labor Earnings, Amsterdam: North-Holland.

Schiller, Bradley R. 1977. "Relative Earnings Mobility in the United States." American Economic Review 67:926-941.

Shapiro, Carl, and Joseph E. Stiglitz. 1985. "Equilibrium Unemployment as a Worker Discipline Device." American Economic Review 74:433-444. 
Solow, Robert. 1979a. "Another Possible Source of Wage Stickiness." Journal of Macro Economics $1: 79-82$.

Solow, Robert. 1979b. "Alternative Approaches to Macroeconomic Theory: A Partial View." Canadian Journal of Economics 12:339-354.

Sorenson, Aage B., and Arne L. Kalleberg. 1981. "An Outline of a Theory of the Matching of Persons to Jobs." Pp. 49-74 in Sociological Perspectives on Labor Markets, edited by Ivar Berg. New York: Academic Press.

Stigler, George J. 1962. "Information in the Labor Market." Journal of Political Economy 70:94-105.

Stoft, Steve. 1982. "Cheat Threat Theory: An Explanation of Involuntary Unemployment." mimeo, Boston University.

Stolzenberg, Ross M. 1978. "Bringing the Boss Back In: Employer Size, Employee Schooling, and Socioeconomic Achievement." American Sociological Review $43: 813-828$.

Thaler, Richard H., and Sherwin Rosen. 1976. "The Value of Saving A Life: Evidence from the Labor Market." Pp. 265-298 in Household Production and Consumption, edited by Nestor Terleckyj. New York: Columbia University Press.

Thom, Gary B. 1983. The Human Nature of Social Discontent. Totowa, NJ : Rowman \& Allenheld.

Tinbergen, Jan. 1951. "Some Remarks on the Distribution of Labour Incomes." International Economics Papers 1:195-207. Tinbergen, Jan. 1956. "On the Theory of Income Distribution." We1twirtschaftliches Archiv 77:155-73. 
Tolbert, Charles M. 1972. "Industrial Segmentation and Men's Career Mobility." American Sociological Review 47:457-477.

Tolbert, Charles M., Patrick M. Horan, and E.M. Beck. 1980. "The Structure of American Economic Segmentation: A Dual Economy Approach." American Journal of Sociology 85:1095-1116.

Viscusi, W. Kip. 1979. Employment Hazards: An Investigation of Market Performance. Cambirdge, MA:Harvard University Press. Wachter, Michael L. 1974. "Primary and Secondary Labor Markets: A Critique of the Dual Approach." Brookings Papers on Economic Activity 3: $637-680$.

Wallace, Michael, and Arne L. Kalleberg. 1981. "Economic Organization of Firms and Labor Market Consequences: Toward a Specification of Dual Economy Theory." Pp. 77-117 in Sociological Perspectives on Labor Markets, edited by Ivar Berg. New York: Academic Press. Weiss, Andrew. 1980. "Job Queues and Layoffs in Labor Markets with Flexible Wage Expectations." Journal of Political Economy 88: $526-538$.

Woodbury, S. A. 1979. "Methodological Controversy in Labor Economics." Journal of Economic Issues 13:933-955.

Yellen, Janet L. 1984. "Efficiency Wage Models of Unemployment." American Economic Review Papers and Proceedings 74:200-205.

Zucker, Lynne G., and Carolyn Rosenstein. 1981. "Taxonomies of Institutional Structure: Dual Economy Reconsidered." American Sociological Review $46: 869-884$. 


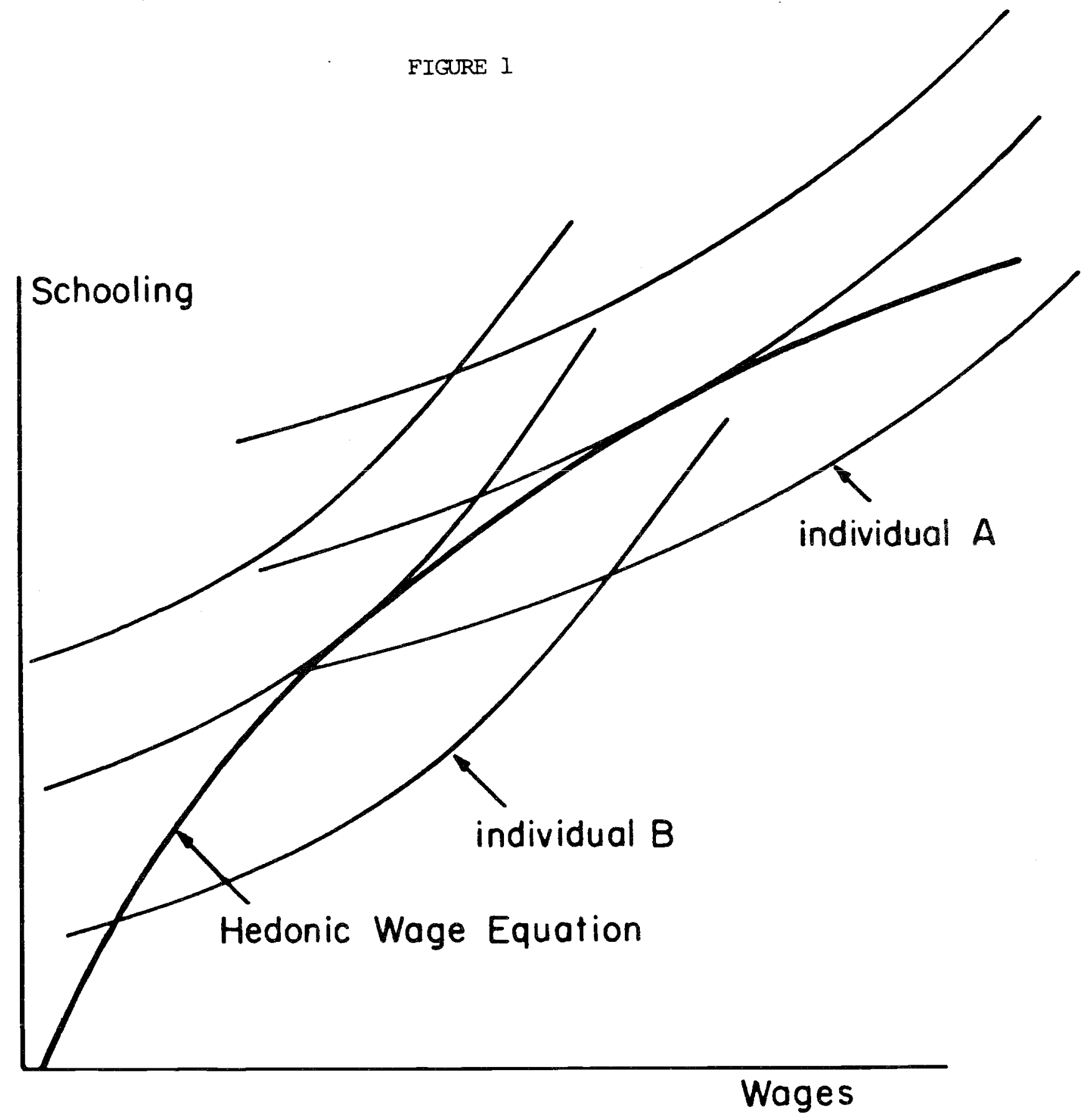


FIGURE 2

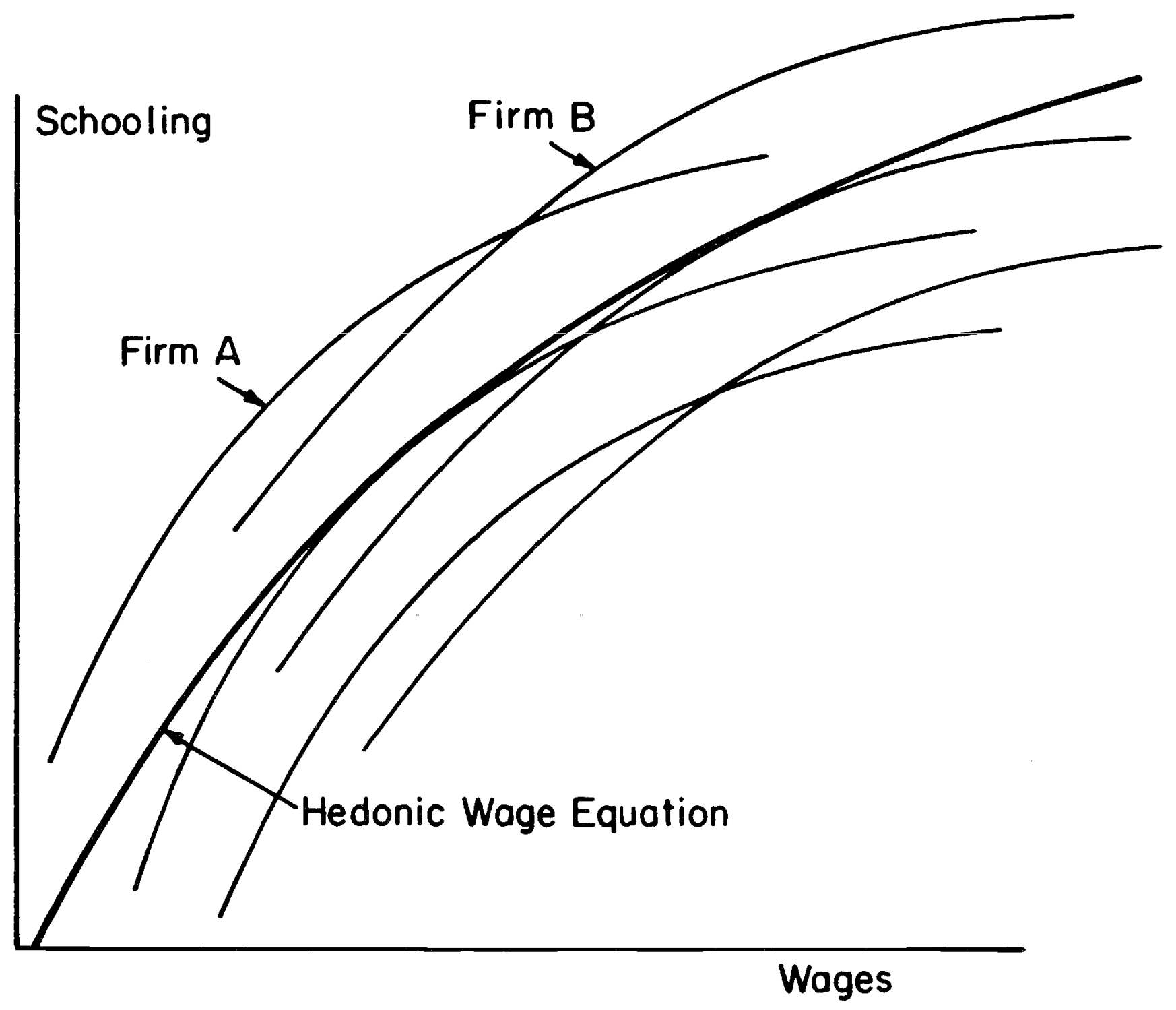


FIGURE 3

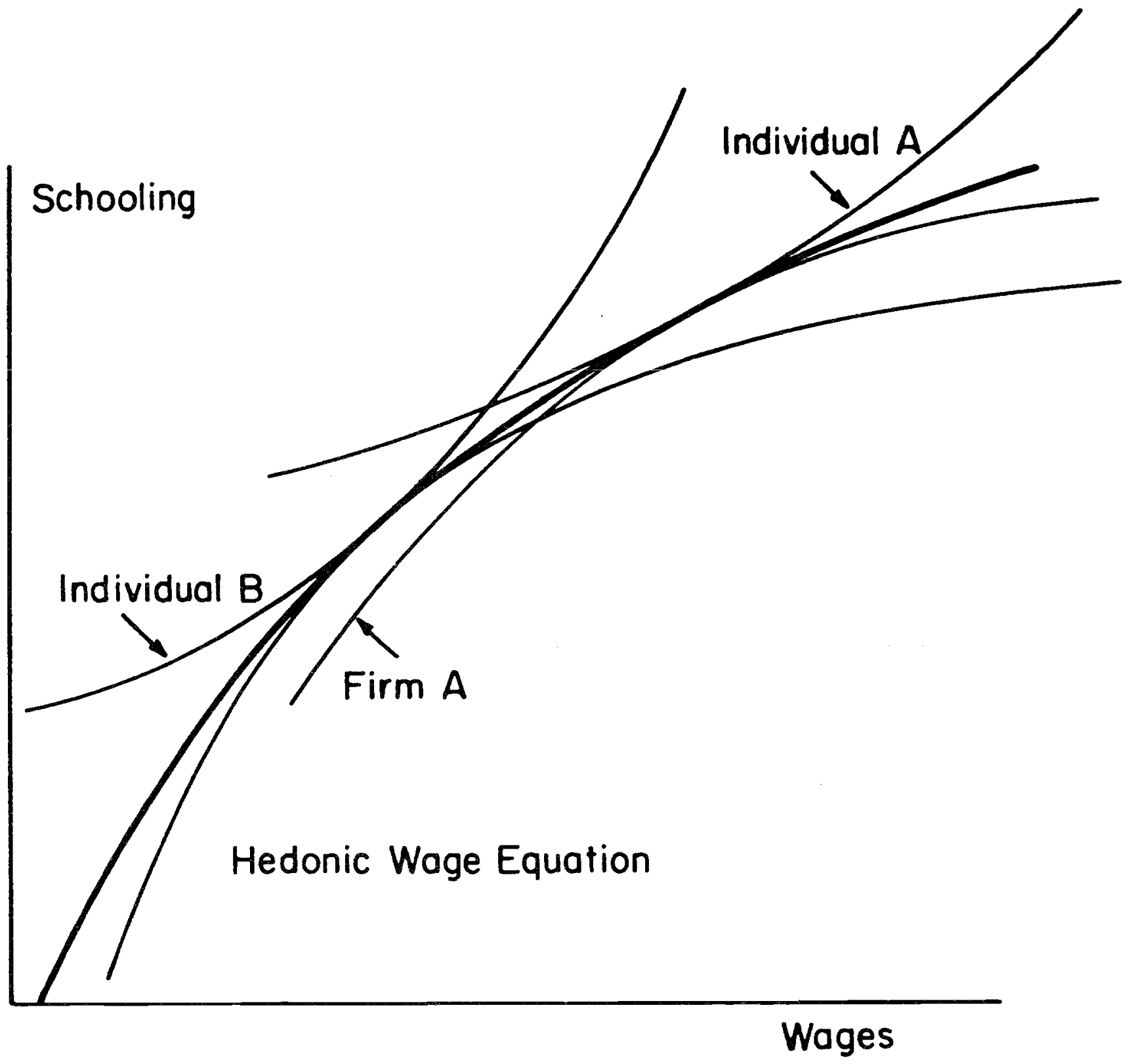

